\title{
Whenua maa wai; he kootiti i eetahi koorero \\ Land by water; a walk through some conversations
}

I te tekau tau, tekau tau maa rima raanei $i$ mahue nei kua puta mai he nukuranga whakaaro kia tirohia te waiwai maaori, wai tai raanei- hei ara koorero moo te whenua me eetahi atu mea. I eetahi o ngaa tuhinga ki raro he paa taumaha rawa i te wai ki te whenua.

There has been a shift towards looking at water, fresh or salt, in the last ten to fifteen years in Aotearoa-New Zealand and a way of looking through, past or over water to other things including land. In some of the literature below there is more of an emphasis on water than land.

Ko te koorero ki raro he arotake teenei moo nga tuhinga o nga waa pahemo noa iho moo te wai me te whenua me ngaa mahi tiaki e tika ana maa taatou e whai. Ko te wawata kia kotiti noa i eenaa tuhinga, kia tata kau raa nga koorero kua puta moo te wai me te kaitiakitanga, kaaore kau he aronga uu e whaia nei. Ko te wawata $i$ koonei kia piri au $i$ te kaupapa engari raa kaaore kau noa he tino whakaotinga.

The discussion below reviews recent literature on water and land and ways of protecting them. The intention has been to browse around that literature, to walk through one or two conversations about water and guardianship without heading for a firm conclusion. This paper tries to stay close to the work discussed without necessarily advancing a distinct argument. 
Ka koorero a Merata Kawharu moo te taiao hei waahi marae (Kawharu ki Selby, Moore me Mullholland 2010: 221- 239). Ka hoatu a Kawharu i teetahi koorero moo kaitiakitanga e aro ana $i$ te waa me te waahi. Ko te taiao e kitea nei teenei hei wao o neheraa e maru ana i nga waahi hirahira.

Merata Kawharu discusses the environment as a marae locale (Kawharu in Selby Moore and Mullholland 2010: 221239). Kawharu gives an account of kaitiakitanga that considers time and space. The environment is seen as an ancestral landscape that encapsulates sites of significance.

I te haere 0 taana tuhinga ka whaingia te mana whenua. He whakaaro hoki ki reira moo ngaa kupu me nga whakaaro e whakamotuhake ana $\mathrm{i}$ toona waahi marae. Ka koorero ia moo te hiikoi whakamuri ki te waa e tuu mai. Ka paa taumaha a Kawharu $i$ te mea he ao koorero te ao Maaori. E ai ki a ia kei te hapori Maaori he kauwhata whakaaro moo ngaa hononga o te putea, te toorangapu me te wairua ki te whenua.

Throughout her paper there is an attention to mana whenua. There is also an attention to terms and concepts that make her marae locale distinctive. She talks about walking backwards into the future.

Kawharu emphasises that this is an orally based culture. There is, in Maori society, she suggests, a sophistication of metaphors about economic, political and spiritual relationships with land.

$E$ noho ana he rahi o teenei whakapae $i$ runga $i$ te moohio $i$ te reo, tae hoki raa ki eetahi kupu e moohiotia naa e eetahi kaaore kau e tino matatau ana $i$ te reo engari raa e matatau ana $i$ eenei kupu (kaaore a Kawharu e tino whai ana $i$ te koorero $i$ te reo). Ko te mea nei, he raarangi koorero e tiimata $i$ te 'tiaki' tae hoki ki te kaitiaki, manaaki, atawhai me eetahi kupu (cf Cleave, 1979, Pocock, 1967, Goldsmith 2003). 
So much of this assertion depends on familiarity with the reo, especially key words in a lexicon shared by people who might not actually speak Maori but know these words (Kawharu does not discuss language use to any great extent). A lexicon is involved beginning with tiaki and then on to kaitiaki, manaaki, atawhai and other words (cf Cleave, 1979, Pocock, 1967, Goldsmith 2003).

He mea moo te mahi koorero me te moohio koorero eenei, aa, e tika ana kia whakaarongia eenei hei mea mahi noa, hei mea torotoro raanei. Ko ngaa kaikoorero e koorero Maaori i ngaa waa katoa, kei te toro atu raatou, ko ngaa mea e whai noa $i$ te raarangi koorero ka aukati keetia raatou.

There are matters of oral performance and understanding and these might be considered as functional or extended. Speakers who use the language to communicate are in an extensive situation and people who use a lexicon only might be confined by that.

E koorero ana a Kawharu moo te tapatoru o ngaa taangata, te taiao me te aahua o te hapori. Ka whai whakataukii ia ki te whakatakoto whakaaro;

Kawharu is talking about a

triangle of people, environment and identity. She uses whakatauki to illustrate her points;

ka mimiti te puna $i$ Taumaarere

ka toto te puna i Hokianga

ka toto te puna i Taumaarere

ka mimiti te puna $i$ Hokianga

When the fountain empties in Taumaarere

The fountain of Hokianga is full

When the fountain of Taumaarere is full

The fountain of Hokianga is empty

or

Tamaki kaainga ika me nga wheua katoa 
Tamaki where fish, bones and all are consumed

Ka whakatuu a Kawharu i teetahi tauira e tae atu naa ki nga wao o waahi, waa, whakapapa hoki, aa, kei roto o eenei te koorero, te tapuwae, te whenua hoki. Ka koorero ia moo te tapuwae hei aahua o te waewae, aa, ka koorero hoki ia moo te ohaaki o te iwi. Kaaore a Kawharu e mea atu, engari raa he aronga anoo kee moo 'tapuwae' hei koorero whakatere. Ka meatia te tapuwae hei koorero moo te tere $i$ te rere, te whai raanei. Ko te tapuwae, hei mea aa tikanga raanei, he mea nuku, he mea noho raanei pea.

Kawharu sets out a model with dimensions of space, time and whakapapa with korero, tapuwae (footprints) and whenua in the middle. She talks about the tapuwae as the footprint of the iwi and talks about the kin group's estate. Kawharu does not mention it but there is another meaning to tapuwae as a chant of movement to ensure speed. A tapuwae is a chant referring to speed in flight or pursuit. The footprint, cultural or otherwise may be fluid as well as stationary.

Ka whakapae mai ia kaaore te Kaitiakitanga he mea moo te taiao noa iho, engari raa he mea e paa hoki ana $i$ te hapori . He mea moo te whanaungatanga $i$ waaenganui $i$ te tangata me te taiao (ibid 2010:227).

She suggests that Kaitiakitanga is not simply an environmental ethic but rather a socio-environmental ethic. It is about relationships between humans and the environment (ibid 2010:227).

Ka toro atu te kaitiakitanga i nga hapori Maaori e tuu naa $i$ te whanaungatanga noo te mea e raarangatia naa nga mea o neheraa, nga mea o te taiao me nga ira hapori moo te aahua, te aronga me te mahi.

Kaitiakitanga finds continuity in Maori kin based communities because it weaves together ancestral, environmental and social threads of identity, purpose and practice.

Ko te taiao he toronga o nga mea katoa e whakatohu nei $i$ te marae. He toronga hoki te marae o te hapori 
whaanui. Ka koorero a Kawharu moo te marae hei tangata, aa, ka whakatakoto ia $i$ te taiuira me ngaa aahua o te ira atua me te ira tangata. Kei te taiao hei waahi marae he raarangi tikanga. Ka whakatakoto a Kawharu $i$ te koorero na James Henare;

When I look at these landscapes I see my ancestors walking back to me.

The environment may be considered as an extension of all that marae symbolize. marae are extensions of a wider community. Kawharu talks about the marae as a person and sets out a model with dimensions of divine principles-ira atua and human principles- ira tangata. The environment as a marae locale contains a series of cultural reference points. Kawharu quotes Sir James Henare saying;

When I look at these landscapes I see my ancestors walking back to me.

Moo kaitiakitanga ka koorero a Kawharu moo te aahua toi o te tangata. Ko te whakatakoto pakiwaitara, he mea nui teenaa e tautokongia e te whakawhiti ki ngaa waahi taonga Maaori.

With regard to kaitiakitanga Kawharu speaks of creative potential. The storytelling aspect of creativity is crucial. maintained through interactions with places of Maori heritage.

Ka mea mai a Kawharu i eetahi whakapae o naianei peenaa $i$ te whakahouhanga o te mana whenua me te tapuwae tikanga $i$ te hapori iwi maha, me te whakahouhanga anoo o teetahi rangatiratanga aa iwi tuuturu. E tika ana hoki kia akona anoo ai te matauranga me ngaa hira o neheraa, a, kia whakatinatatia ai eenei (peenaa maa nga mahi toi o whaikoorero, whakairo, tukutuku me te oho anoo o te maatauranga o koro maa kui maa i te rangatahi).

Kawharu sets out some present challenges such as reestablishing mana whenua and a cultural footprint in a multicultural society, and re-affirming credible tribal leadership. And there is a need to re-learn traditional 
knowledge and values and apply them (such as through the arts of formal speech making, carving and tukutuku and reviving traditional knowledge among rangatahi).

He mea uaua te waahi o te taaone. He taawhiti $i$ te whakaaro o Merata Kawharu me taa Stokes raaua ko Barton $i$ te New Zealand Herald i te tau 2006 moo te whakatau o Ngaati Whatua. Ka mea mai a Barton raaua ko Stokes $i$ te uaua o te mahi kereeme moo te taaone ka tata teenaa hei mea kaaore e taea pea. Ka whakaatu hoki raaua i te nukunuku ki teenaa taha, teenaa raanei o nga kaituhi hiitori $i$ te tino taumaha o te taaone ka whai taha ngaa kaihiitori, kua ngaro ngaa tuhinga hirahira, aa, ka puta mai he take moo te rangatiratanga.

The space of the city would seem to be problematic. There is a real gap between the work of Merata Kawharu and the work of Stokes and Barton in the New Zealand Herald in 2006 and 2007 on the Ngati Whatua settlement. Stokes and Barton show how difficult, impossible almost, the city situation is in the claiming process. They show how, in the intense pressure of the city, historians take sides, important documents are lost and leadership issues arise.

Ka puta mai i teenaa he tuunga noa iho, aa, e ai ki teenei kaituhi, he mea whakakati $i$ te iwi taketake $i$ too raatou anoo taaone.

This produces a stalemate which, the present writer would argue, amounts to a lock out of the locals in their own city.

Kua tuhi a Neocosmos (2003) moo te katinga ki waho o ngaa rawakore me ngaa raawaho me te tapatapa o teenaa hei tangata whenua, teenaa hei raawaho $i$ te rohe 0 Awherika ki te Tonga. He uaua pea ki te paanui $i$ taa Barton, aa, kia kore e puta ai nga whakaritenga. Neocosmos (2003) has written of the lock out of the poor and the foreign and the definition of people as official citizens or not in the context of the cities of Southern Africa. It seems hard not to read Barton's work in particular and begin to make comparisons. 
Ka tuhi a Merata Kawharu (2010:235-6) moo te motu i waaenga $i$ te waahi marae me te taiao. He motu teenei $i$ te rerenga koorero moo te waahi taketake, he motu e ngau ana, e huri kee ana te reka o te tikanga. $E$ hono ana teenei ki eetahi atu tuhinga i te kohinga o Kaitiaki tae kau raa ki eenaa naa Veronica Tawhai raatou ko Rachel Selby me Pataka Moore. Ka whakaatu te koorero naa Tawhai moo raawaho $i$ teenei motu $i$ te waahi marae me te taiao $i$ te koorero e whakaatu ana $i$ te motu $i$ te hiitori me te koorero whenua.

Merata Kawharu (2010:235-6) writes of a disconnection between the marae locale and the environment. This is a break in oral reference, a break in the storytelling of the locale, a break that strips out and warps the richness of the culture. This relates to several other pieces in the collection of Kaitiaki in particular those by Veronica Tawhai and Rachel Selby and Pataka Moore. Tawhai's consideration of rawaho shows this disconnection between marae locale and the environment as it shows a disconnect between history and geography.

Ko te upoko o taa Veronica W.H. Tawhai tuhinga ko Rawaho, in and out of the environmental engagement loop (Selby, Moore me Mulholland 2010: 77-94), aa, ko teenei teetahi o ngaa mea tiaho $i$ te kohinga, Kaitiaki (2010). Ko oona tohu aro ko te Resource Management Act me te Local Government Act 2002. Ko toona aronga kaupapa, ka mea paitia $i$ eetahi raarangi noa $i$ te tiimatanga o taana korero;

The chapter by Tawhai is entitled, Rawaho, in and out of the environmental loop (Selby, Moore me Mulholland 2010: 7794), and, this is one of the sparkling pieces in the collection, Kaitiaki (2010). Her points of reference are Resource Management Act and the Local Government Act 2002. The thrust of her topic is well put in some lines at the beginning of her essay;

In the tribal lands of another, the manner in which Maori individuals can express their interests as Maori is unclear. 
Similarly there are concerns about the extent to which Maori, living far from their tribal homelands can effectively be involved in the management of tribal and public environmental resources.

(ibid 2010: 77)

$E$ koorero ana a Tawhai moo ngaa taangata e kiia whaanuitia hei raawaho, taura here, mataawaka raanei. Ko taana tuhinga, kei mua teenei i teena naa Rangi Mataamua me Pou Temara i teetahi tuunga e whai mai moo diaspora. Ka koorero a Tawhai moo ngaa raawaho, eenaa e noho ki waho o too raatou anoo whenua kaaore kau he raarangi tootika aa hapori ki te waa kaainga, ki te waa oho raanei. Ka whakatakoto a Tawhai $i$ te koorero naa teetahi kaiwhakamoohio e toru ngaa waahi e meatia nei; te waa noho, te waa whanau me te kaainga o neheraa (ibid 2010:78).

Tawhai considers people who are known variously as rawaho or taura here or maataawaka. Her argument precedes that of Rangi Mataamua and Pou Temara in a later article that refers to diaspora. Tawhai is talking about the situation of rawaho, people who live outside their homeland without clear lines of civic relation to the homeland or the place that they live in. Tawhai quotes one informant to the effect that three sites are involved; where the person lives, where they were born and their ancestral homeland (ibid 2010:78).

Kei te koorero a Tawhai moo te tuu o ngaa raawaho $i$ raro $i$ te ture e kiia nei ko te Local Government Act o te tau 2002. He rerekee anoo te aronga o te kupu Maaori $i$ te kupu raawaho. Ko te aronga o 'Maaori' ka haangai teenaa ki te tangata noona te whenua. Ko te aronga o 'raawaho', noo waho o te whenua teenaa. Ko teetahi o ngaa aronga moo raawaho, he hau noo te moana.

Tawhai is talking about the rights of rawaho under the Local Government Act of 2002. There is a sense in which the words rawaho and Maori are at odds. Maori means to be native to natural to an area. Rawaho means to be from 
without. One meaning of rawaho is that of a wind from the sea.

Ka mea mai ia, tokowaru o te tekau o ngaa taangata pakeke atu $i$ te rua tekau maa rima ki te rua tekau maa iwa, kua nuku raatou i te waa kotahi mai i te tau 2001. Naa reira he mea nui te whakaaro o 'raawaho'.

She notes that eight out of ten 25-29 year old Maori have moved at least once since 2001. With this in mind the idea of rawaho is important.

Ka hokihoki anoo mai a Tawhai ki te Tiriti o Waitangi hei kaupapa moo te whanaungatanga $i$ waaenganui $i$ nga raawaho me nga kaunihera. Ahakoa he mana whenua, raawaho raanei ko te whanaungatanga ka noho teenaa $i$ runga i te Tiriti o Waitangi.

Tawhai falls back again and again in the article to using the Treaty of Waitangi as the basis of the relationship between rawaho and councils. No matter whether mana whenua or rawaho the relationship is always based on the Treaty of Waitangi.

A primary problem is the engagement of Maori from an assimilationist view of citizenship and not upon a basis that is culturally appropriate or recognizant of the disadvantaged socio-historical position that Maori bear when engaging with local authorities.

Cheyne and Tawhai 2007

Ka mea a Tawhai, kaaore he tino uu te mahi maa ngaa raawaho $i$ ngaa rohe noho me ngaa rohe aa iwi, aa, he ngaawari rawa maa ngaa raawaho e piri ki nga take o te motu.

Tawhai suggests a lack of clarity about roles locally and in tribal areas and that it is easier for rawaho to identify with national issues.

I teetahi waa ka mea ia;

At one point she suggests; 
for many Maori their collective identity overshadows their individual one, at least with regard to environmental management (2010: 91).

Mai i taa Tawhai ka puta he paatai moo ngaa tikanga taiao. $E$ toro atu ngaa raawaho ki ngaa tikanga taiao $i$ te reanga o te motu. Engari ko te mana whenua kei a raatou ngaa tikanga tuatahi, me kii, moo te taiao.

Questions to do with the distribution of environmental rights arise from Tawhai's work. Rawaho relate to environmental rights on a national basis. But at the local level the locals, the mana whenua as she calls them have first rights, so to speak, regarding the environments.

Ahakoa kaaore ia e whai ana i teenei kaupapa e tika ana kia whakaarongia te ipurangi. Kei te noho te tangata Maaori, Aha raanei $i$ te ao whanui, araa, te taiao whaanui. Kei te whakawhiti whakaaro te tangata i ngaa amuamu o teenaa toopito, teenaa o te ao.

Although she does not mention it the internet is importabt to consider. The person, Maori or otherwise, lives in the wide world, the wide environment. The person shares in the concerns of this part or that of the world.

Ka whakamaumahara mai teenei $i$ ngaa tuhinga $i$ whakatakoto ai i a Van Mejl me Goldsmith $i$ taa raaua mahi (Van Mejl and Goldsmith 2003). Ko Van Mejl tonu raa o te tokorua, ka whai ia $i$ te tauira tohatoha o 'whanauhapu-iwi'. Ko Veronica Tawhai, ka whakaatu ia i eetahi aahua e haangai mai.

This evokes the literature set out by Van Mejl and Goldsmith in their work (Van Mejl and Goldsmith 2003). Van Mejl especially of the two seems to follow a straight whanauhapu-iwi model of distribution. Veronica Tawhai shows some of the other dimensions involved.

I eetahi waa ka kitea he hononga tuuturu i waaenganui i nga mea raawaho me te tangata whenua, te mana whenua raanei. Ki Tamakimakaurau, hei tauira, ko Te Tira Hou te marae o Tuuhoe kei waho o too raatou anoo rohe. Ki 
Rotorua ka whakatikatia te marae o Mataatua e Te Arawa maa Tuuhoe. He mea tawhito teenaa, aa, ka kitea i teenaa he mea tawhito ngaa aahua o ngaa raawaho kaaore he mea hou. I ngaa tau 1950s-60s ka hui ngaa Maaori ki te waahi i kiia ai ko te Maaori Community Centre ki te rori o Fanshawe .

Sometimes there is a distinct relationship between the rawaho group and tangata whenua or mana whenua. In Auckland, for example, the Tuhoe have Te Tira Hou as their own marae outside of their area. In Rotorua Tuhoe have Mataatua Paa which was arranged for them by Te Arawa. The latter is of long standing and illustrates that the rawaho/diaspora situation is not new. In the 1950s and 1960s Maori people used to gather in the Community Centre in Fanshawe Street.

Ki taa raaua tuhinga i Kaitiaki ka whakaatu a Temara me Mataamua (Selby, Moore and Mulholland 2010: 95-108) $i$ te toro o te aahua raawaho $i$ taa raaua hoatuhanga $o$ te tatau he $81 \%$ o Tuuhoe e noho ana ki waho o te Urewera (Nikora 2000:39).

In their article in Kaitiaki Temara and Mataamua (Selby, Moore and Mulholland 2010: 95-108) show how extensive the rawaho condition is when they give figures to show that $81 \%$ of Tuhoe live outside the Urewera.(Nikora 2000:39).

\section{Ka paatai raaua;}

They ask

are we becoming Tuhoe by name but not by nature?

Ka whakapae raaua he hononga kaha to Ngai Tuuhoe ki tua o te rima tekau tau, aa, kaaore he kaha too Ngai Tuuhoe ki raro o te whaa tekau tau. Ka noho teenei pea $i$ te wehenga o te ahi kaa me te taura here, aa, he peenei teenei $i$ te mana whenua me raawaho $i$ taa Tawhai. Ka whakapae hoki a Temara raaua ko Mataamua he 5\% noa iho pea te rahi o Tuuhoe e whakauu ana $i$ too raatou Tuuhoetanga. 
They suggest that those Tuhoe over 50 have a relatively strong relationship with the environment and those 40 and other do not have such a strong relationship with it. This goes with a distinction between ahi kaa and taura here and this is reminiscent of Tawhai's mana whenua and rawaho. Temara and Mataamua also suggest that the people who actively affirm their relationship with Tuhoe might be as low as $5 \%$.

Kei taa raaua naa koorero $i$ te tau 2008, te whakaaro e hoomaingia te ngahere ki a Tuuhoe $i$ raro $i$ te Whakatau Tiriti, aa, i te waa tuhi teeraa pea he teitei kee nga wawata. Ko teenei whakaaro he mea aahua whakatoi i nga tau 2010-11. Ka koorero a Temara raaua ko Mataamua moo te hokihanga o te ngahere $i$ eetahi waa, aa, e koorero hoki ana raaua moo te kupu 'diaspora' i eetahi waa.

There is the suggestion, made in 2008, that the Treaty Settlement might give the forest back to Tuhoe and when this article was written expectations may have been high. The promise of return has become something of a tease in 201011. Sometimes Temara and Mataamua talk about the return of the forest and sometimes they talk about the term 'diaspora'.

E ai ki a Temara raaua ko Mataamua he matau ika i te whakahokianga o te ngahere inahoki he waahi raruraru moo nga mea peenaa $i$ te paihamu te ngahere. He peenei teenei $i$ te hurihanga o nga awa hei keri hamuti e koorerongia naa e Selby me Moore.

Temara and Mataamua suggest the return of the forest might have fishhooks in that they will be coming to own a pest contol problem. This is like the turning of rivers into sewers discussed by Selby and Moore.

I te tau 2010 ki Taipa ka kitea he mea oorite tonu. Ko te aahua kua mea atu te Taraipunara o Waitangi e hoki te whenua maa teetahi anoo huarahi inahoki e mahia eetahi mea e te kaunihera. Engari kaaore anoo kia taea teenaa mea noo reira ka waiho poouri te iwi, aa, kaaore raatou e hoki ki te whenua. Kua aukatia te iwi $i$ too ratou whenua. 
In 2010 at Taipa the same thing can be seen. The Waitangi Tribunal seems to have promised the return of land through a process whereby a third party, the council does certain things, this does not happen and people perceive a promise broken a return to the homeland delayed or prevented. There is in fact a kind of lockout from the homeland occurring, a blockage to the return.

I te katoa o teenei ka puta mai he paatai moo te aahua o te tangata. Ki tua o te waru tekau orau o Tuuhoe e noho ana ki waho o te Urewera, aa, he rahi kee nga mea 0 Tuuhoe e noho kaaore mahi ana noo reira he uaua ki te hono $i$ te mahi, te nohoanga raanei ki te aahua o te tangata.

In all of this there are questions of identity. With over $80 \%$ of Tuhoe outside the area and with most in the Urewera out of work it is difficult to relate identity to vocation or location in the Urewera.

He mea anoo te reo. Kaaore a Temara me Mataamua e haangai ana ki teenei kaupapa $i$ taa raaua tuhinga engari raa he mea nui te reo kia motuhaketia te aahua o te tangata.

Language is another matter. This is not addressed by Temara and Mataamua to any great extent but it is a very important marker of identity.

He uaua te haere o ngaa mea e haangai ana ki te aahua o te tangata. Ko te waru tekau orau o Tuuhoe me Ngaati Kahu, me kii, e noho ana ki waho o too raatou naa rohe, ka whakakuitihia oo raatou anoo aahua mai $i$ waho $i$ teetahi reo kaaore e koorerongia e raatou. Kia tikia he kupu mai $i$ te koorero naa Veronica Tawhai, kei te tuu raawaho raatou moo te reo.

The politics of identity that are being worked out here are difficult. The eighty percent or more that live outside of the traditional rohe of, say, the Tuhoe or Ngati Kahu areas are defined from without in a language that they sometimes do not 
speak. To take a word from the writings of Veronica Tawhai they stand as outsiders, rawao to the language.

He taawhiti $i$ te iwi e koorerongia e April Bennett (Selby, Moore and Mulholland 2010: 175-184), ko Te Arawa me Tainui, ki eetahi iwi. Ko Te Arawa me Tainui, kua whakauu te kirimanu $i$ waaenganui $i$ a raatou me te Karauna e tuuwhera atu ki teetahi waa mahi tahi ai.He rerekee teenei ki a Tuuhoe, Ngaati Kahu raanei.

There is a gap between the iwi discussed by April Bennett (Selby, Moore and Mulholland 2010: 175-184), Te Arawa and Waikato-Tainui and other iwi. The former have secured agreements with the Crown that seem to usher in a time of cogovernance and/or co-management. This is a contrast with such iwi as Ngati Kahu and Tuhoe.

Ko te take ko te nako o te waa kaainga. Ko nga take o te taiao e waihotia ana $i$ te nuinga o te waa maa Ngai Kaakariki, ka mau rawa eenei e nga mea whakapakari te waa nehe o te Maaori.

At issue is the valence of the homeland. Environmental issues that are sometimes left to the Greens are taken up in earnest by Maori heritage advocates.

E ai ki a Meihana Durie, he hononga ki te whenua me te taiao te puutake $\mathrm{i}$ te taketakehanga, aa, ka toro ia ki a Walker (1990: 11-15) moo teenei. Kei te taha o te whanaungatanga ki te taiao e rima ngaa mea; te waa, te aahua $o$ te tangata, te rerenga, te tika o te hapori me te maatauranga i runga $i$ te rahitonutanga.

Mason Durie says that a bond with the land and the natural environment is the fundamental factor of indigeneity and he cites Walker (1990: 11-15) to this effect. Beside the relationship to the environment there are five factors that Durie suggests; time, human identity, continuity, social order, and a system of knowledge on the basis of sustainability.

Ka whakatakoto a Durie $i$ te koorero moo taketakehanga me oona aahua- tikanga, taiao, waa hokikia whakaraarangihia hei mea nui kia moohio ai nga 
hirahira puta noa (2010: 247). Ka koorero ia moo Salmond mai i 1978(ibid 166-67) me Kawharu mai i 1977(60-62). Ka koorero ia moo ngaa taonga o Ihipa. Ko te taketaketanga, te putanga noa me te waa waatea hoki ngaa aahua o teenei ako moo neheraa.

Durie is making a case for indigeneity with its cultural, ecological and temporal dimensions to be listed as an important criteria in determining outstanding universal value (2010: 247).He quotes Salmond from 1978 (166-67) and Kawharu from 1977 (60-62). He talks about the pyramids. Indigeneity universality and timelessness are features of this kind of heritage study.

E koorero ana a Durie moo te honohonotanga, te mauri, te rerenga, te hira-aa-wao me te utu hoki. Ka whakapae ia ka taea te tatau o eenei moumou mea. Ka mea hoki ia ka tuu te reo $i$ teetahi rohe, aa, ko teenei teetahi aahua o te taketaketanga.

Durie talks about connectedness, mauri, continuity, contextual significance and reciprocity. He suggests that assessment and measurement of such things can be achieved. He also suggests that language is set in a locale and that this is a feature of indigeneity.

He ngaawari ki te kite he raarangi kupu whai mai ai i te tapa o te whenua. Engari raa e mea mai a Durie kaaore e taea te wehe o te reo $i$ toona anoo naa wao?

A lexicon is obviously involved in the way in which a landscape is named but is Durie saying that languages are inextricably bound to environments?

Ka taea te maatakitaki i a Durie raatou ko Kawharu maa hei whakatipuranga o teetahi mahi whakanui o ngaa waa o nehe? Ka whakapae mai a Zemgulys (2008) i te hanga o teetahi mahi o nehe ki Ingarangi tae noa ra ki Ranana $i$ te whakamutunga o te rau tau tekau ma iwa me te timatahanga o te rau tau rua tekau, aa, ka koorero ia moo te mahi naa eetahi kaituhi peenaa i a E.M.Foster, T.S. Eliot, me Virginia Woolf. I te tauira o Aotearoa e kitea naa 
i nga koorero naa Durie raaua ko Kawharu ka noho te mahi o nehe i te taiao, aa, ki Ranana ka kitea teenaa $i$ te ao toi , $i$ te mahere whare me eetahi mea. $E$ aha he mahi o nehe ki te Maaori?

Is it possible to see the work of Durie, Kawharu and others as the development of a heritage industry. Zemgulys (2008) suggests the making of a heritage industry in England especially in London in the late nineteenth and early twentieth century and discusses writers like E. M.Forster, T.S.Eliot and Virginia Woolf. In the case of Aotearoa as seen in the articles discussed by Durie and Kawharu case the heritage industry is situated in issues of the environment while in London it was situated in the world of the arts, architecture and elsewhere. London was made old. What will a heritage industry make Maori?

He mea pai he mahi moo nehe peenaa moo Ngai Maaori ki Aotearoa? Teeraa pea ko Ahitereria me ngaa taaone nui - Aotearoa nga tino waahi tipu moo te reo me eetahi mea. Kia whakaaro ai taatou moo Ngaati Kahu me Tuuhoe, aa, he $80 \%$ o nga mema iwi ki waho o te waa kaainga, he aha te pai o te titiro ki te waa kaainga?

Is such a heritage industry useful for Maori in Aotearoa/New Zealand? Points of growth and development of the language might be in Australia and in the urban centres. With population figures from Tuhoe and Ngati Kahu, as discussed later, showing over $80 \%$ of iwi members living outside of the home locale is an emphasis on heritage sites productive?

Mena kei te tika te whakaaro he ngaawari rawa maa nga mea rawa e ako e whakaaroaro hoki teeraa pea ka puta teenaa hunga rawa ki Ahitereria hei taraiwa moo te reo me oona aahuatanga. I a taatou e huri whakamuri ana teeraa pea e pahemo taatou i nga pito tipu. He mahi pai rawa pea kia aata titiro kei hea kee nga kaikoorero o apoopoo, aa, e hanga $i$ teenaa. 
If it is true that a middle class with greater resources for study and reflection than other people drive a language that middle class could well develop in Australia in an entirely different locale to the point of origin. As we encourage what was we mightmissing the growth points. The task might rather be to look clearly and accurately at where potential speakers of the language are now and build on that.

He tino mea te aahei ki te hari tikanga, heoi raa te pai o nga mea e noho tuuturu. Ka aro a Tawhai ki nga aahua e toru; te waa taketake, te waahi whaanau me te waahi noho. $E$ rua ngaa nuku nui $i$ te wao aahua. Ko te mea tuatahi te wehe $i$ te waa kaainga ki teetahi taaone nui ki Aotearoa, aa, ko teetahi ko te nuku ki teetahi taaone ki Ahitereiria. Kaaore e taea pea e eetahi te noho aa whakaaro ki te tuutururanga o te hau kaainga, aa, he peenaa $i$ te hiinaki moo eetahi (cf Smith, 1993).

It is important to emphasise the portability of culture as well as its static aspects. Tawhai points to three identifications, the tribal homeland, where people were born and where they live. There are two major shifts in the geography of identity. One is leaving the homeland for a New Zealand city and one is leaving the New Zealand city for an Australian city. Dwelling on the stasis of the locale of origin might not be possible for many people and might be something of a cultural cage for some (cf Smith, 1993).

Ko ngaa mea o nehe tae noa ki te taiao, he mea maa ngaa mea rawa noa e whai?

Are issues of heritage including the environmental heritage inherently middle class?

Ka oho mai a Selby raaua ko Moore i a taatou. Ka whakaatu raaua kaaore kau noa teenei he kongakonga wao (cf Tapsell 1998), engari kau raa he putanga anoo mai o te wao kia kitea ai ngaa awa, i teetahi waa te waahi ora o nga taangata $i$ te Manawatu me te Horowhenua hei keri hamuti. I taa raaua timatanga hiitore ka whakaatu a Selby 
raatou ko Mulholland ko Moore i te tuu whakarunga o Ngai Paakehaa i runga $i$ te Maaori me te tauira o te tahuritanga o nga awa hei keri hamutiti.

Selby and Moore jerk things back to reality. They show that this is not just a collapse of space (cf Tapsell 1998) but also a reformulation of space so that rivers, once the living space of people in the Manawatu and Horowhenua areas become sewers and drains. In their historical introduction Selby Mulholland and Moore show the priority of Pakeha interests over Maori with special reference to the use of rivers as sewers and places for the discharge of all kinds of effluent.

I muri noa ka mea atu a Selby raaua ko Moore (2010:43) kaaore te kaunihera me ngaa mea hou e aata kite ana, aata titiro raanei $i$ te marae me nga whare tata. I teetahi waa, i ngaa tau 1950-60, naa te kino o ngaa mea katoa he itiiti kee ngaa taangata $i$ noho ai $i$ te waahi marae. He tauira teenei $e$ whakaatu in extremis te hurihanga o te nohoanga awa hei keri hamutiti.

Later Selby and Moore say (2010:43) that in many ways Ngati Pareraukawa, the marae and the surrounding homes were invisible to the Borough Council and the new settlers of Levin. At one stage in the 1950s things were so bad that there were very few people living in the marae area. This is an example that shows the river dwelling site turned into a sewer in extremis.

Ki te raawhiti ka noho ra teetahi roto paru, ki te hauaauru he whare poaka, ki te tokerau ko te awa o Hokio e rere paru ana, aa, ki te tonga ka tohatohatia te hamuti, he tahuna rapeti ki reira hoki.Ko ngaa mea e kiia naa he mea whakapai peenaa $i$ te waahi hamutiti whenua maroke ki Te Pot' $i$ te Tonga, he mea aapiti kee raa teenaa ki te wao paru o Ngaati Pareraukawa. Ko te awa Anawahata e tata mai, he mea paru i te rerenga mai i ngaa paamu.

To the East there was a polluted lake, to the west a piggery, to the North the Hokio stream became polluted and to the south sewage was spread and there was a large rubbish 
dump. The development of so-called solutions such as the dry land sewage disposal at 'the Pot' to the south actually contributed to the polluted environment of Ngati Pareraukawa. The nearby Anawahata stream became polluted by farm runoff.

Ka tata a Selby raaua ko Moore $i$ te rangahau aa wao $i$ te mahi naa raaua $i$ te pukapuka miniti o te marae, te aata whakatipu o te mahi tuhi me te mahi mahere hoki. Ko te Ture o te RMA 1999 he mea nui, aa, kei roto $i$ te pukapuka miniti o te marae nga whakapae moo teenei ture $i$ te mea he pou huihui teenaa moo Ngaati Pareraukawa.

Selby and Moore lend themselves to action research or at least field based research in their use of the marae minute book, careful document development and planning. The 1991 RMA seems to have served as a point of positive reference and the marae committee minute book recorded many objections under this Act as it became something of a rallying point for Ngati Pareraukawa.

Ka whakatakoto a Mulholland i teetahi koorero rerekee, he mea tika hoki taana, moo te awa 0 te Manawatu e rere noa nei hei keri hamuti peenaa $i$ taa Selby raaua ko Moore moo te awa o Hokio.

Mulholland tells an extraordinary and generally true tale of the Manawatu River as a sewer which shows the same kind of thing that Selby and Moore are saying regarding the Hokio Stream.

Ka koorero ia moo te hapahapa i ngaa waa katoa naa ngaa kaunihera moo te paru o te awa. $E$ ai ki a Mulholland, ngaa whakaaaetanga o naaianei tonu peenaa i te 2003 Dairying and Clean Stream Accord, he mea e tika ana kia aata paataingia.

He talks about a systematic failure of councils to deal with the pollution of the river. Even recent agreements such as the 2003 Dairying and Clean Stream Accord seem to have been of questionable value according to Mulholland. 
Ka whakatakato a Mulholland i te koorero naa Moore kia mea atu te awa hei waahi nukunuku maa ngaa taangata i ngaa waa o mua;

Mulholland quotes Moore to show how the river afforded a locale through which groups of people traditionally moved;

The Manawatu River was so rich with quality eel that it was not uncommon for entire hapu to relocate their people to areas closer to the Manwatu river in the fishing season for no other reason than to fish for eel... Eel became the staple diet for many Maori in the Horowhenua and the Manwatu and their reliance on this food source made it devastating when the number of eel began to dwindle. Moore 2006:3

He kino kau te hiitori i mea mai i a Mulholland o te tuku hamuti ki te awa o Manawatu. Mai i 1890 me kii ki 1958 ka puta noa te hamuti. I te tau 1968 i whakatuu ai teetahi waahi whakatika hamuti. Ka puta mai ngaa mea paru mai i a Papaioea, Feilding, Foxton, Linton Military Camp me Mangahao Village. Ka whiuia te rapiti ki te awa $i$ eetahi waa. Mai i ngaa whare puutia me ngaa whare makariri ki Fielding me Longburn ka puta mai te paru miti. Ka aapiti teetahi whare rakuraku wuuru, tunu tinana kararehe hoki ki teenei whakaparutanga (Mulholland 2010 128).

The history of sewage discharge into the Manawatu River as outlined by Mulholland is disconcertingly vile. From the 1890s until 1958 raw sewage was discharged into the river. In 1968 there was a new treatment plant established, Sewage and effluent came from Palmerston North, Feilding, Foxton, Linton Military Camp and Mangahao Village. Rubbish was tipped into the river at various places. Meat wastes came from abattoirs and freezing works in Feilding and Longburn. A wool scour and boiling down works in Feilding also contributed to the pollution (Mulholland 2010 128).

Ka haere tonu teenei koorero whakamataku me ngaa mate ika $i$ te kore haa 1978 me 1984. I te tau 1985 ka whakatuungia he waahi whakatika hamuti engari $i$ te tau 
1993 ka pai tonu ki te tuku hamuti tuuturu ki te awa. Ka puta mai eetahi paatai moo te tuku maa one o te paru i te waahi whakakii whenua ki Awapuni ki te awa i 2006. Ka koorero a Mulholland moo teetahi reta ki te ao naa Taakuta Mike Joy i teeraa tau tonu e whakapae ana ka iti haere ngaa ika maaori nukunuku.

Mulholland's horror story continues with fish kills due to lack of oxygen in 1978 and 1984. In 1985 a secondary sewage plant is established but in 1993 it is still possible to discharge raw sewage into the river. There were questions about the discharge of leachate from the landfill at Awapuni into the river in 2006. Mulholland refers to an open letter from Dr Mike Joy in the same year suggesting that the migratory native fish species are in decline.

Ka koorero a Mulholland moo ngaa mahi arotake tae noa ki te Memorandum of Understanding $i$ waaenganui i a Taanenuiarangi o Manawatu me New Zealand Pharmeceuticals i taea ai ahakoa te paru e haangai ana ki a Muaupoko me Ngaati Raukawa $i$ raro iho $i$ te awa. Ka mea hoki a Mulholland i ngaa koorero naa Buddy Mikaere kia kore ai e haere whakararo te mauri o te awa.

Mulholland mentions review processes including a Memorandum of Understanding between Tanenuiarangi $o$ Manawatu and New Zealand Pharmaceuticals that occurred despite pollution affecting Muaupoko and Ngati Taukawa further downstream Mulholland also notes comments by Buddy Mikaere in 2008 that the mauri of the river would not deteriorate.

I te haere o taana waananga ka koorero a Mulholland moo Alex Barnes kia maarama ai te kupu 'mauri';

In the process of his argument Mulholland cites Alex Barnes to give a definition of mauri;

...the life energy or unique life sense that gives being and form to all things in the universe. Tikanga had emerged around this duty bringing with it an intimate knowledge and 
understanding of our local environments and a set of rules that guide oi raro iho I teur way of life both spiritual and secular.

(Barnes 2006)

Ka whai pea a Mulholland i te whakaaro, he mea uu te waahi marae. Kaaore teenaa i te tika pea i ngaa waa katoa. He nohohanga o te Maaori $i$ te Manawatu $i$ a raatou e whai ana $i$ te hurihanga $o$ te ao me te rahi $o$ te kai. Kaaore raatou $i$ noho ai $i$ ngaa waahi uu. Engari e ai ki ngaa koorero ka whai kawa raatou ahakoa kei whea raatou. Ko te kawa pea he mea nui rawa $i$ te waahi noho.

Mulholland does seem to posit a fixed marae space. This may not be always or altogether accurate. Maori in the Manawatu and Horowhenua and elsewhere lived in nohohanga, temporary dwellings following the seasons and the supply of food. They did not live in fixed marae locales. However they followed kawa wherever they were from all accounts. Locale might not be as important as ritual process.

He rerekeehanga $i$ waaenga $i$ te hiitori me te koorero whenua i ngaa tuhinga i waanangahia $i$ mua. Ko teetahi o ngaa mea $i$ taa Kawharu tuhinga, he whakaaro moo te nehe uu. Ko taana tuhinga, he mea ki waho o te waa pea. Ka haria taatou ki taa Levi Strauss(Levi Strauss 1968) me toona whakaaro moo te pakiwaitara me te hiitori, ki te hapori mahana me te mea makariki, he mea aa tikanga, he mea raanei o Uropi peenaa i ngaa mea i koorerongia e Levi Strauss me Sartre.

There is a difference between history and geography involved in the papers so far discussed. One feature of Kawharu's paper is the notion of a stable past. Her paper is almost a-historical. This takes us back through to Levi Strauss' idea of myth and history, of cold or cool societies of a traditional kind and hot ones like the European ones that Sartre and Levi Strauss were considering (Levi Strauss 1968).

Aapiti atu $i$ te whakaaro o te noho uu he whakaaro hoki i koonei moo te ao atua uu, te ao pakitara uu hoki. Ka whitiwhiti teenei ki taa Durie honohono ki taa 
Salmond, Te Ao Tawhito o te tau 1978 me oona anoo raa aahua uu.

In addition to an idea of fixed domicile there is the idea of a fixed rather than a fluid cosmology and mythology. This ties in with Durie's reference to Salmond's Te Ao Tawhito of 1978 with its fixed categories.

Aapiti atu anoo ko te whakaaro o ngaa rohe uu i te waa puta mai o Ngai Paakehaa me ngaa whakataukii uu rawa mai i te waa paanui, tuhi hoki.

There is also the notion of boundaries fixed at contact and proverbs frozen at literacy.

Ko teenei he mihini, kauwhata raanei i puea ake hei whakautu ki te haramai o te Paakehaa, aa, ka kitea hei mea whakararo here. Ka whakatakoto teetahi toopito ki waho o te hauaauru, he waahi makariri, kaaore $i$ te mahana, he mea uu kaaore i te mea nukunuku, he rahi rawa atu te pakiwaitara $i$ te hiitori.

This is an intellectual machine or construct that arose in response to colonialism and was seen as a decolonizing tool. A given point outside of the West was posited where people were cool not hot, fixed not fluid, where locale was concrete and there was much more myth than history.

Peenaa ai i taa Zembulys (ibid) moo te mea e kiia naa ko Heritage Studies $i$ te whakataawhito o Raanana ko te kaha ko te whakarerekeehanga o te ao o naaianei me te ao o noonanahi, kiikii i a Neheraa. Kia rerekee ai te toopito ki waho o te Hauaauru kia taawhiti kia waho rawa atu $i$ te waa me te waahi o te Hauaauru.

As Zembulys (ibid) suggests with regard to Heritage Studies in the making old of London the effect is to make the difference with now and the world of then, steeped in the Past, so the point outside of the West is made different, distant and out of Western time and space.

I te tauira o Raanana e koorero ana taatou moo te whakamea anootia o te paakeke. I te tauira o te Maaori e koorero pea taatou moo te whakamea anootia o te taiao. 
Kei te mahi naa Michael Brown me Michael Goldsmith he raarangi o nga take e haangai ana ki te kaitiakitanga, te paatai noo wai teenaa, teenaa raanei, te tikanga me te taiao.Ko te mea whakamutunga (Goldsmith, 2009:300) e koorero ana ia moo te mea kei mua;

In the case of London we might be talking about the reification of age. In the case of Maori we might be talking about the reification of nature. There are a number of issues related to kaitiakitanga, ownership, culture and nature to be found in the work of Michael Brown and Michael Goldsmith. The latter (Goldsmith, 2009:300) considers the former;

Michael Brown famously asked 'Who owns native culture?' This paper revisits that question by analyzing what happens to culture when the culturally defined boundary between it and nature becomes salient in the context of disputes between indigenous and settler populations.

Ka haere tonu a Goldsmith ki te whakaatu i taana anoo kaupapa;

Goldmith goes on to state his own project;

My case study is the dispute between the New Zealand government and Maori tribal groupings concerning ownership of the foreshore and seabed. Having been granted the right to test their claims in court in 2003, Maori groups were enraged when the government legislated the right out of existence in 2004. Though the reasons for doing so were clearly political, contrasting cultural assumptions appeared to set Maori and Pakeha (New Zealanders of European origin) at odds. While couching ownership of part of nature as an IPR issue may seem counter-intuitive, I argue that as soon as a property claim destabilizes the nature/culture boundary, IPR discourse becomes pertinent

The issue becomes even more complex when cultural and linguistic phenomena come into play. For example, ownership claims in Maori and other Polynesian languages are inflected by an inherent distinction between possessive articles that imply either alienability or inalienability (the well known a versus $o$ 
opposition).To say that something is mine or ours may therefore imply something other than straightforward ownership in the Western sense.

\section{I teenei anoo tuhinga ka whakatakoto a Goldsmith i eetahi mea e haangai pea ki te rerekeehanga o te ' $a$ ' me te 'o';}

In the same paper Goldsmith makes several other interesting points which may apply to the o-a distinction;

One might say that the individualistic nature of such ownership is embodied, a point derived from C.B. Macpherson's analysis of the rise of possessive individualism. (Macpherson) This work treats as historically pivotal the development of a modern axiom that first and foremost individuals own themselves. Perhaps it is time to introduce the antiphonal phrase possessive collectivism to capture the notion that (indigenous) groups possess one thing above all others: their culture. Indeed, at one level, the group is the culture, the origins of which are presumed to be ancient and the existence of which is treated as timeless-an ideological convenience within what has come to be known in anthropological circles as the politics of tradition.

This well-known strategy can apply creatively to much more than the canonically authentic parts of indigenous cultures. After the release of the film based on his novella Whale Rider, writer and leading figure of the contemporary Maori cultural renaissance Witi Ihimaera stated that he took "a tribal approach to writing." He continued, "I would much prefer that I was better known as a person who has helped the entire Maori literary tradition rather than my own career." (cf Black 2003) It is as if, rather than individuals owning cultures (or bits of cultures), their cultures possess them. There is a clear analogy between this idea of people being owned by their cultures and indigenous rhetorics surrounding land and other parts of the (natural) environment. I have heard, for example, some Maori assert that their land owns them, rather than the other way around. Land and culture in this respect are both 
conceptualized (culturally, of course) as inalienable. If, as in some indigenous perspectives, no temporal limits are applied to curtail ownership (and of course it is only cultural convention that requires such curtailment), the ownership of nature and the ownership of culture are placed on the same footing. In short, for practical purposes, culture and nature merge. In some versions of this argument, it was only Western thought that ever conceived of separating them in the first place.

(Goldsmith, 2009: 304)

Teeraa pea e tika ana kia whakanoho aa Goldmith naa koorero $i$ te taha o teetahi koorero naa Te Ururoa Flavell moo Bruce Stewart ki te marae o Tapu te Ranga ki Te Whaanganui a Tara (Flavell 2010). Heoi anoo kau raa kua koorero a Goldsmith moo ngaa whare $i$ mua $i$ taana tuhinga;

Goldsmith's arguments might be placed alongside a speech made by a member of the Maori Party, Te Ururoa Flavell when talking about Bruce Stewart at Tapu te Ranga marae in Wellington. (Flavell 2010). Actually, Goldmith has talked about houses earlier in his paper (Goldsmith, 2009: 326);

It's like asking the apparently tautological question, Who owns my house? The immediate presumption is that I own my house. True, the reality could turn out to be more complex: The answer could be me plus my partner, my spouse, my parents, my landlord, my bank, the state, and so forth. But even if I do not actually or wholly own my house, there will be little doubt that the house is, firstly, owned in some identifiable way and, secondly, owned by some person or persons identifiable in law, either in their own right, acting as agents for others, or represented by institutions. To paraphrase Honoré (Honore 1961) ownership can be regarded simply as the greatest possible interest in a thing whose ownership is legally recognized. In my world, which is strongly influenced by the Anglo-American and European legal tradition, finding out who 
owns a house thus becomes a matter for empirical, rather than philosophical, investigation.

\section{Kia huri ai taatou ki taa Te Ururoa Flavell;}

To turn to the speech of Te Ururoa Flavell;

A couple of years ago Bruce Stewart shared some of his ideas around Maori housing policy with the Maori Party, beginning with the premise, 'Kei a ratou $i$ hanga te whare....kei te whare $i$ hanga nga tangata'.

It was a philosophy that Bruce himself had been immersed in for over thirty years - they who build the house are also built by the house.

Flavell, 2010

E koorero tahi ana a Flavell raaua ko Goldsmith moo ngaa taonga tuku iho, aa, ka haria taatou ki a Shirres (Schirres JPS 91) me te tapu e haangai naa ki eenaa mea e mau naa $i$ te 'o'. Ko nga mea haangaia e te tangata tonu, ka mau eenaa $i$ te ' $a$ '.Kia nuku ai te whare $i$ te mea hanga ki te mea tuu tonu ka nuku hoki i te ' $a$ ' ki te 'o'. Ka haangai mai pea taa Agathe Thornton i koonei.

Both Flavell and Goldsmith are talking about taonga tuku iho and this takes us back to Schirres (Schirres JPS 91)and the tapu associated with such treasured collective property that usually takes o. Things that you make, at least as long as you are creating them usually take a. As the house moves from artifact to collectively shared property and shared consciousness, from mahi to taonga it comes to take o. Agathe Thorntons's (Thornton 1991)work might apply here.

\section{Kei te haere tonu a Goldsmith;}

Goldsmith continues;

In addition, the fact that some claims to both cultural and natural property have a perduring quality may stem from quite different logics of ownership (at least as expressed in legal argument). On this view, indigenous cultural property is owned in perpetuity because it is owned not by individuals but, (here Goldsmith refers back to Brown) by groups that in principle could live forever (thereby circumventing the time-limited 
provisions of patent and copyright regimes). Indigenous natural property, by contrast, is ultimately owned in perpetuity-like everyone else's-because if it is subject to a claim for return or redress, it can only be because the property was earlier alienated by force or fraud and not because of some presumed difference in the legal status of the owner.

If (and this is a big if) it was not alienated in those ways, it unequivocally belongs to some other party, not to indigenous people

\section{Ka haere tonu a Goldsith;}

Goldsmith goes on to say;

In principle, therefore, Western law is perfectly compatible with both indigenous and nonindigenous claims to nature in perpetuity, even if in practice that principle has often been ignored or manipulated when it comes to indigenous minorities in settler societies.

\section{E koorero ana a Goldsmith moo te taiao me te waa;}

Goldsmith is talking about nature and time;

between capitalist and noncapitalist notions of property is that the latter sets no time limit (or perhaps it sets indefinitely long time limits) on the ownership of culture. Western capitalist regimes, by contrast, allow such longevity only in the case of nature: One owns land or material property unless and until it is alienated.

Kaaore e taea te paanui i a Goldsmith meenaa e waihotia a Brown. Ka whai a Brown i te tikanga, ka whai a Goldsmith $i$ te taiao. I teetaahi waa ka tipu te aahua o te koorero, he kaupapa teenei moo te waa, aa, ka tae pai i a Goldsmith te koorero moo teenaa. He kaupapa hoki teenei moo te waahi me te hinengaro hoki.

One cannot read Goldsmith without reading Brown. The latter deals with the ownership of culture, the former with the ownership of nature. At a certain point it all gets a bit bigger; it is about the ownership of time as Goldsmith points out carefully and well. It is about the ownership of space and and it is about the ownership of mind. 
He tika pea taa Tapsell whakaaro i whakatakoto ai i a Kawharu moo te takarepa, te kongakonga raanei o te wao (cf Cleave, 2010). Ko teenaa pea teetahi puutake riri moo te iwi. He ngaawari ki te kite $i$ te riri peenaa $i$ te tuhinga naa Makere Mutu.

Tapsell's thought, quoted by Kawharu is that there has been a collapsing of space. Perhaps this is a reason for the anger of the iwi. It is easy to dense that anger in the writings of Margaret Mutu.

Ka mea mai a Mutu ahakoa e mana, e tiaki te tuu o te Kaitiaki $i$ raro $i$ te RMA 1991 e whakapae nuitia ana, whakamataku hokitia i eetahi waa. Ko te kaha o taa Mutu (2010) ko te piripiri $i$ te maramara $i$ eetahi tauira mai $i$ te Te Tai Tokerau. Ka whakaatuu tonu eenei $i$ te poorangi o te Far North District Council me nga kaiwhakapakari whenua. He tiro whakararo e kitea nei ki a Ngaati Kahu. Ka koorero a Mutu moo te kaikiri o te Paakehaa, ko te mea e kiia nei ko White Supremacy.

Mutu says that while the role of kaitiaki might be respected and protected under the 1991 Resource Management Act it is severely challenged and threatened on many occasions. The strength of this article is the close attention to detail in several examples from the Far North. These show again and again the flaunting of sense by the Far North District Council and developers. There is a general disregard for the rights of Ngati Kahu, the iwi involved. Mutu talks about white supremacy.

E ai ki a Mutu he waru tekau orau o Ngaati Kahu e noho ana ki waho o te rohe o te iwi, ko te nuinga o te eenei hei te taone.

Margaret Mutu notes that $80 \%$ of the Ngati Kahu population live outside the tribal area, mostly in cities.

Ka huri pai a Mutu ki a Maaori Marsden me McCully Matiu. Ko te mea whakamutunga naa, ka whakatakoto eetahi o aana koorero kia kitea te haangai o te Maori ki te taiao hei kaitiaki. Ka taea pea te whakanoho o eenei 
whakaaro $i$ te taha o oo Flavell $(20100$, ki oo Goldmith (2009) me oo Brown (2003).

There is an important set of references to Maori Marsden and McCully Matiu. The latter is quoted to show an identification of Maori with the environment as kaitiaki. This could be cross referenced to the work of Flavell (2010) about the house and the people in it, and to the work of Goldsmith (2009) and Brown (2003).

Ka kitea teenei $i$ teetahi koorero naa McCully Matiu i te ripoata me te rangahau ki te mahere aa tai moo Aotearoa i 1994;

This is seen in a quote from McCully Matiu in the report and recommendations of the board of inquiry into the New Zealand coastal policy statement in 1994;

In Maori cultural terms, all cultural and physical elements of the world are related to each other and each is controlled and directed by the numerous spiritual assistants of the gods. These spiritual assistants often manifest themselves in physical forms such as fish, animals, trees or reptiles. Each is imbued with mana, a form of power and authority derived directly from the gods. Man being descended from the gods is likewise imbued with mana although this mana can be removed or violated if it is abused. There are many forms and aspects of mana of which one is the power to sustain life. Maoridom is very careful to preserve the many forms of mana it holds and in particular is very careful to ensure that the mana of kaitiaki is preserved. In this respect Maori become one and the same as kaitiaki (who are, after all, their relations) becoming the minders for their relations, that is the physical elements of the world.

Ka whakatakoto a Mutu i teetahi raarangi koorero moo te ture e tautoko ana $i$ te tuu o Maaori hei kaitiaki.

Mutu cites a comprehensive array of law protecting the role of Maori as kaitiaki.

Ki aana tauira he nui nga whakarawekee $o$ te taiao peenaa raa $i$ te tuku atu o te wai peenaa $i$ teenaa e meatia naa e Selby me Moore i te rohe o Hokio. 
In her examples there are a range of violations of the environment particularly regarding discharge of water comparable to those cited by Selby and Moore in the Hokio area.

Ka mahi tahi a Mutu me Kawharu me eetahi atu moo te whakaaro kei Ngai Maaori te kaitiakitanga. Kei te mana whenua te kaitiakitanga. He kauwhata teenei e mau kee naa i a Tawhai i toona whakaaro moo raawaho, ngaa taangata e noho ana $i$ teetahi whenua kaaore kau noo raatou te mana whenua, aa, kei waho o te kaitiakitanga tonu.

Mutu shares with Kawharu and other writers the notion of owning/ownership of guardianship. Mana whenua own kaitiakitanga. This is an axiom that Tawhai seems to take on board from the contrary view with her concept of rawaho, people living in an area in which they do not have mana whenua and are outside the immediate loop of environmental responsibility.

Kia hoki ai taatou ki ngaa awa e kitea teetahi tauira rerekee, whakamoohio kee hoki o te whanaungatanga $i$ waaenganui i te iwi me te karauna i te ripoata naa Alistair Bisley. I te Report of the Land and Water Forum: a Fresh Start to Freshwater(2010) ka mea mai a Bisley e tika ana maa te iwi e koorero tootika ki te karauna $i$ mua $i$ te koorero ki ngaa kaunihera.

Coming back to rivers there is a curious but telling example of iwi-state relations in Alstair Bisley's report. In the Report of the Land and Water Forum: a Fresh Start to Freshwater(2010) Bisley argues that iwi should deal directly with the crown before arrangements are made with local councils.

Ko te puutake o teenei, ka mea mai a Bisley, he rerekee teenaa kaunihera ki teenaa $i$ te mahi me te arotake e whaingia nei. He oritenga ki teenei tauira $i$ eetahi atu waahi o te wao peenaa $i$ te ipurangi, te pere, me eetahi anoo mea tae hoki ki te takutai moana. 
This is bercause, says Bisley, of variation in performance and criteria from one council to another.

This is an example with parallels in many areas that have to do with space including communications, the foreshore and seabed and other areas.

He mea taumaha te ripoata naa Bisley noo te mea ka whakaatu teenaa $i$ te wao whaanui; kei te mimiti te wai maaori ki Aotearoa nei noo reira e kore e kore e puta mai ngaa tohatohanga me te utu moo te wai maori. Kei koonei te niao, me kii o te whakaaro, whenua maa wai.

Bisley's report is very important as it shows the wider context; water in New Zealand is now so scarce in Canterbury now and elsewhere soon that allocation and costs for water are likely. This gives an edge to the land by water proposition.

Aapiti atu i te tahuri o ngaa awa hei keri hamuti, he mea hari tohu utu hoki ngaa awa.

Not only are the waterways placing Maori dwelling places into sewers they are also starting to carry price tags.

E hia ngaa take moo te wai, he aha te uaua o eenei mea katoa? Hei tauira, te mahi naa Petrobas ki te rohe moana o Raukumara. He mea maa te ao katoa te rapu moo te hinu ki Raukumara. E rapua naa te hinu i nga moana teitei o te ao.

How many issues are involved in water and how complicated can it all get? Take the activity of Petrobas in the Raukumara sea area. The exploration of the Raukumara area for oil and gas by Petrobas is an international matter. The exploration is being done in international waters.

Noo hea a Petrobas? Kei raro, me kii, I te haki o Brazil. Engari, he nama nui oo Petrobas ki ngaa peeke o Haina.

Where is Petrobas from? It is under the flag, let's say, of Brazil but it owes a lot of debt to the banks of China.

Engari kau ra he mea kee moo te motu, mo Aotearoa/Niu Tireni nei e whakaaengia naa e Gerry Brownlee i tuu maangai ai moo te kawanatanga nei. 
And then again this is a national matter agreed by Gerry Brownlee on behalf of the New Zealand Government.

He raruraru $i$ koonei noo te mea kaaore e toro atu te ringa $o$ te ture $o$ teenei whenua ki nga mea $e$ haere ana $i$ nga moana teitei $i$ raro $i$ te haki o teetahi whenua atu $i$ Aotearoa. Ki te iwi nei, ko Te Whaanau a Apanui, he mea anoo teenei noo te mea kaaore he uu te kawanatanga o te rohe o Raukumara.

There is a problem here in that the arm of the law of this country does not apply to people and vessels ravelling under the flag of another country. The iwi concerned, Te Whanau a Apanui are faced with something else, an uncertainty of state in the area of Raukumara.

He tauira pai teenei noo te mea $i$ te nuinga o ngaa waa kei raro tonu te iwi i te kawanatanga o Aotearoa. He aha te aha kia kore he peenei ai?

This is a good example as for the most part the iwi are under the comtrol of yhe Government of New Zealand. What happens when those controls are not thee?

He mea hoki teenei moo nga kaunihera inahoki e tata a Raukumara ki te taha o eetahi rohe kaunihera. Ka hoki te whakaaro ki taa Tracy Whare (ibid2010) e koorerongia ki raro.

This is also a matter for councils inasmuch as Raukumara is near some council boundaries. The thought returns to Tracy Whare's work (ibid 2010) discussed below.

Ko taa April Bennet ki Kaitiaki( 2010: 175-184) moo te uruhanga mai o te Maaori ki te rangatiratanga moo wai maaori, he mea nui kia paanuihia taana $i$ te taha o te Ripoata e kiia nei ko LAWF. Ka koorero a Bennett moo ngaa whakatau o Tainui me Te Arawa moo ngaa awa me ngaa roto me ngaa mahi aa tikanga me ngaa mahere e whai mai.

April Bennett's work in Kaitiaki (2010: 175-184) on Maori participation in fresh-water management is important to read alongside the LAWF report. Bennett talks about the 
settlements of Tainui and Te Arawa regarding rivers and lakes and how matters of strategic direction and cultural redress are being worked through.

He peenaa a Tainui me Te Arawa moo te wai maaori ki a Ngaati Porou moo te takutai moana, He iwi aarahi eenei i eetahi atu.

Tainui and Te Arawa in the fresh water area are in a comparable position to Ngati Porou regarding the foreshore and seabed.

Kia hoki ai taatou ki ngaa mea tino taumaha kei taa Bisley, e rua eenei. Ko eenei ko te rohenga me te tohatanga o te wai;

To return to Bisley's work there are two main things. These are limits and allocation of water usage and rights. Bisley says in the Executive summary;

Central government has not used national instruments to provide direction though two are now in preparation. Few regional councils have had the consistent and coherent policy frameworks to put the necessary management regimes in place. In the nature of things it is difficult to get agreements about what limits should be, how quickly they should be achieved and who should bear the cost- but stakeholders and iwi have not always been fruitfully engaged, either at the national or the regional levels. Monitoring and enforcement of rules, consents and their conditions has also been variable.

Kaaore he rohe tuuturu moo te wai maaori ki Aotearoa. Ka whakaarongia e te kawanatatanga e nga kaunihera hoki hei mea kore e mimiti, engari kua moohio mai raano kaaore $i$ te peenaa teenaa.

There are no effective limits on water in Aotearoa/New Zealand. It has been regarded by local and national government as an infinite resource when clearly this has not been the case for a long time.

\section{Ka whakapae a Bisley i taana whakatepenga;}

Bisley is suggesting in the Executive summary that; 
...regional councils and consent holders should be able to withhold water where the environmental conditions of the consent are not met.

Kei te koorero a Bisley moo teetahi tikanga aa noho kaaore kau he whakaaro rohe- he peenaa te wai $i$ te wao $e$ whakaarongia teenei he mea kaaore rohe. He whakapae nui teenei moo te kaitiakitanga.

Bisley is referring to a culture of occupation which has had no idea of limit, where water, like space was seen as infinite. This is a big challenge for guardianship.

He whakaaro nui teenaa moo te wao inaaianei. Hei tauira te ture hou moo te takutai moana. I teenei waa ko ngaa aahuatanga moo Ngaati Porou noa iho ngaa mea e whati $i$ te porohita o te waahi waaenga e huri nei $i$ a Aotearoa. Ko te rangahau o Tracey Whare (Whare, 2010) mo Ngaati Porou me te Karauna, ka whakaatu teenaa i eetahi o nga mea taumaha moo teenei tae hoki ki nga aahua $i$ waaenganui $i$ te iwi me te kaunihera;

At this stage it seems that only the arrangements with Ngati Porou will break the ring of the commons around Aotearoa in any significant way. The research of Tracey Whare on the Ngati Porou arrangement with the Crown (Whare, 2010) shows the complexity of this and also the matters between iwi and council;

Given the FSA premise that the public foreshore and seabed is vested in the Crown and that Maori have no right to compensation is this Bill the best that could be achieved? Does the tweaking of existing decision making processes simply mean business as usual? If so, then all the concerns around the FSA continue to be played out in this Bill. Given the Government's previous negotiation processes, it also sets the precedent for future negotiations with iwi and hapu. With the government's decision to review the RMA, the FSA and the proposed constitutional review, it remains to be seen what effect those reviews will have on this Bill. If the Bill is enacted its 
implementation will be closely monitored by all even more so by its supposed beneficiaries.

The Foreshore and Seabed Act: Five years on, where to from here?

Tracey Whare

In

Maori and the environment:Kaitiaki

Edited Selby, Moore and Mulholland

Huia Publishers 2010: 59-75

Ka whakapae a Whare he rahi ngaa hua e puta ki ngaa kaunihera kia puta ai te mea e mohiotia hei 'customary title' ki te iwi.

Whare suggests that local councils such as that in Gisborne and on the East Coast actually gain a lot when iwi get customary title.

\section{Hei mea whakatepe}

Review

Ko te koorero ki runga, he hikoikoi noa iho i eetahi koorero, aa, kaaore kau he whakaotinga uu rawa. Ko taa Tawhai, he wehenga hou pea.

The above is a walk through conversations and there are no clear conclusions. Tawhai's writings stand out as a venture into new territory.

Ko Kawharu raaua ko Goldsmith, tae noa raa ki a Durie, ka tau raatou $i$ te waa rohe kore, e uu naa $i$ te rohe kore noa atu. Ko teenei te ako mai raano, atu raanei hoki moo te whakamau tuuturu o te wao o te taiao hoki. Ka puta mai ngaa paatai moo te mahi e tika ana kia mahia ai $i$ te rangahau peenei.

Kawharu and Goldsmith both come to rest, as does Durie, on the unlimited time, the time fixed in limitlessness, permanent ownership of the locale, of nature. This is the anthropology of eternity Questions about its use and its useby date might now arise. 
Kei te timata, kei te hokihoki raanei ki te titiro $i$ te wai hei taonga hirahira. Kua puta mai eetahi mea hou moo teenaa taonga maa runga $i$ te ahuatanga $o$ te waahi waatea $i$ te Ture Takutai me te tohatoha, nga tikanga nukunuku o te wai maaori e whakapaengia nei $i$ te Ripoata LAWF hoki.

Maori are beginning or perhaps they are going back to seeing water as a significant resource. There are now new forms of ownership of that resource via the commons of the Takutai Act and the allocation and suggested system of rights transfers of fresh water in the LAWF Report.

Ko te whanaungatanga o te wai me te whenua, kua hurihia teenaa mai $i$ te haramai o te Paakehaa. Ki Uropi $i$ te tipu o te mahi ahuwhenua ka whakarungatia te whenua i eetahi ahua. Ko nga awa me te moana, he mea aukati noa eenei moo te whenua, he toopito kerikeri. Ko teenei ko te wai maa whenua, kaaore $i$ te whenua maa wai.

The relation of water and land may have been rephrased since contact. In Europe the development of agriculture meant that land was given priority in certain ways. Rivers and sea became boundaries for land, points to drain toward. This is water by land and not land by water.

E tika ana pea kia whakaaro ai taatou moo te wai. I a taatou e whakaaro ana moo te wai e tika ana pea kia whakaarongia teenaa maa te wai e tata mai, e noho ki runga, ki raro raanei.

It is appropriate perhaps that we think of water. When we think of land we might consider it through the water around, under and on it.

He aha too taatou moohio i te wai? Kei te moohio taatou moo te koorero naa Wiremu Tamihana moo te wai maaori me te wai tai. Kei te moohio hoki taatou moo te mahi i te wai hei mea whakanoa. Ko te wawata kia puta anootia eetahi whakaaro, paatai hoki moo te wai kei runga. 
What do we know about water? We know aboiut the distinction Wiremu Tamihana made with fresh and salt water. We also know about the use of water in whakanoa. It is hoped that the above brings forth more thoughts and questions about water.

\section{Bibliography}

Barnes, A. 2006 Citing Whaia te Mahere Taiao a Hauraki: Hauraki Environmental Plan (16/06/2006) Submission made by Alex Barnes Resource Consent Number 102909 by

Fonterra Cooperative Group Ltd for the Discharge to the Manawatu River of Milk Processing Wastewater and Condensate Cooling Water from their Longburn Factory.

Barton, Chris 2006 Iwi wrangle takes a new turn, New Zealand Herald, Dec 1

Barton, Chris 2007 When history is on trial, New Zealand Herald, March 17

Bennett, April 2010 Uncharted Waters- recent settlements as new spaces for enhancing Maori participation in fresh-water management and decision making in Selby, Moore and Mulholland, 2010: 175-184

Berkes, F., Colding, J., Folke, C. (Eds.), 2003. Navigating Social-Ecological Systems, Building Resilience for Complexity and Change. Cambridge University Press, Cambridge.

Black, Eleanor 2003 "Lucky to Be Born a Maori." New Zealand Herald, January 25 G1-G2. (Cited in Goldsmith 2009:326)

Brown, Michael F. 2003. Who Owns Native Culture? Cambridge: Harvard University Press,

Cheyne, C.M. and Tawhai, V.M.H. 2007 He Wharenoa Te Rakau, Ka Mahue Maori Engagement with local government. Knowledge, Experience and Recommendations, Palmerston North, Massey University 
Cleave, Peter 2000 The Nurturing Shield; a collection of Essays on the Maori language, Napier, Campus Press

Cleave, Peter 2009 Iwi Station, Campus Press

Cleave, Peter 2009 Takutai, the foreshore and seabed, Campus Press

Cunningham, B.T, Moar, N. T, Torrie, A.W, Parr, P.J, (1953) A survey of the western coastal dune lakes of the North Island, New Zealand. Australian Journal of Marine and Freshwater Research. 4(2): 343-386

Death, F., and R. G. Death. 2005. River Health of the Manawatu-Wanganui Region. Massey University

Feeny, D., Berkes, F., McCay, B.J., Acheson, J.M., 1990. The tragedy of the commons: twenty-two years later. Human Ecology 18 (1), 1-19.

Findlayson, Chris, Attorney General, Press Release of 6 September 2010

Flavell, Te Ururoa MP for Waiariki 2010, Speech to the National Maori Housing Hui, Rotorua 22 March

Goldsmith, M 2003;280-294, Culture, for and against: patterns of "culturespeak" in New Zealand, in Van Mejl and Goldsmith

Goldsmith, Michael 2005 Culture in Safety and in Danger. In Michèle D. Dominy and Laurence M. Carucci (eds), Special Issue: Critical Ethnography in the Pacific: Transformations in Pacific Moral Orders. Anthropological Forum 15(3): 257265

Goldsmith, M. 2009 Who owns native nature? Discourses of rights to land, culture, and knowledge in New Zealand. International Journal of Cultural Property, 16, 325-339

Gould, John D, 1992 'Maori' in the population census 19711991, New Zealand Population Review, 18

Harmsworth, G.R, Barclay, Kerr, K, Reedy, T (2002a) Maori Sustainable Development in the 21st Century: the importance of Maori values, strategic planning and information systems, He Puna Korero, Journal of Maori and Pacific Development 
Harmsworth, G.R. (2002) Indigenous concepts, values and knowledge for sustainable development: New Zealand Case Studies, Presentation at the $7^{\text {th }}$ Joint Conference, Preservation of Ancient Cultures and the Globalization Scenario

Hingston, Ken 2006 Foreshore and Seabed in Mulholland 2006 Honoré, A.M. 1961 "Ownership." In Oxford Essays in Jurisprudence, edited by A.C. Guest, 107-47. Oxford:

Clarendon Press (cited in Goldsmith 2009:327)

James, Colin 2010 in the Dominion Post on Sep 13th

Ka'ai, Tania 2008 The Role of Maori in Tertiary Education Institutions Te Kaharoa Vol 1 No 1

Levi-Strauss, C 1968 The Savage Mind (Nature of Human Society) University of Chicago Press

Kawharu, I.H. 1977 Maori Land Tenure; Studies of a Changing Institution, Oxford University Press

Kawharu, Merata 2010 Environment as a marae locale in Selby, Moore and Mulholland

Kymlicka, W 1995 Multicultural Citizenship: a Liberal Theory of Minority Rights, New York, Oxford: Clarendon Press

McDonald, Laurence 1995 Film as a Battleground: Social space, gender conflict and other issues in Once Were Warriors. In Ilusions 24 Spring: 15-23 Macpherson, C.B. 1962 The Political Theory of Possessive Individualism: Hobbes to Locke. London: Oxford University Press (cited in Goldsmith 2009: 327)

Moore, P. 2006 Submission by Pataka Moore: Resource Consent Number 102909 by Fonterra Cooperative Group Ltd for the Discharge to the Manawatu River of Milk Processing Wastewater and Condensate Cooling Water from their Longburn Factory.

Mulholland, Malcolm and contributors, 2006 State of the Maori Nation; twenty first century issues in Aotearoa, Reed Mutu, Margaret 2010 Ngati Kahu kaitiakitanga in Selby, Moore and Mulholland (13-36) 
Neocosmos, Michael, 2006 From Foreign Natives to Native Foreigners: explaining xenophobia in contemporary South Africa, Dakar: Codesria

Nikora, T.R. 2000 Ko wai a Tuhoe? A Report for the Waitangi Tribunal and the Office of Treaty Settlements.

Park, G. (1995) Nga Ururoa (the groves of life)- ecology and history in a New Zealand Landscape, Victoria University Press, Wellington

Pocock, J.G.A. 1967 The History of Political Thought: a Methodological Enquiry in Philosophy, Politics and Society, Runciman and Laslett, Basil Blackwell, Oxford

Ruru, Jacinta 2009 The legal voice of Maori in Freshwater Governance. A Literature Review, Lincoln University, Landcare Research

Salmond, A. 1978 Te Ao Tawhito: A Semantic Approach to the Traditional Maori Cosmos. Journal of the Polynesian Society Vol. 87 no1 166-167

Schirres, M.P. Tapu Journal of the Polynesian Society 91:29:51

Selby R, Moore P, Mullholland, M 2010 Maaori and the environment:Kaitiaki Huia Publishers

Smith, Cheryl Te Waerea, 1993 'The natives are restless' in Murphy, T (ed). Treaty of Waitangi Flora and Fauna Claim (Wai 262).

Stokes, Jon 2007 Waitangi Judge Slams 'Insulting' Treatment, New Zealand Herald Mar 17

Tapsell, P 1998 Taonga: A Tribal Response to Museums, D.Phil thesis, University of Oxford

Tawhai, Veronica W.H. Rawaho, in and out of the environmental engagement loop (Selby, Moore and Mulholland 2010: 77-94)

Taylor, C 1992 Multiculturalism and the "Politics of Recognition", Princeton, Princeton University Press Thornton, Agnes 1998 Journal of the Polynesian Society Vol 107 No 4 December 
Tipa, Gail and Tierney, Laurel (April 2006) A cultural Health Index for Streams and Waterways: a tool for nationwide use A Report prepared for the Ministry for the Environment

Turia, Tariana, March 272010 'Restorative Justice: turning the tide' speech to National Restorative Justice Aotearoa Practitioners Conference

Brentwood Hotel, Kilbirnie, Wellington

Van Meijl, Toon, 2003:260-279 Conflicts of Redistribution in Contemporary Maori Society: Leadership and the Tainui Settlement In Van Meijl and Goldsmith

Van Meijl, Toon and Goldsmith Michael, Postcolonial dilemmas: reappraising justice and identity in New Zealand and Australia , Journal of the Polynesian Society, Volume 112, September 2003, No3 Van Meijl, Toon and Goldsmith, Michael, 2003: 205-218 Introduction: Recognition, Redistribution and Reconciliation in Postcolonial Settler Societies. In Van Meijl and Goldsmith

Walker $1991 \mathrm{Ka}$ whawhai tonu matou: struggles without end, Penguin Books

Whare, Tracey, 2010: 59-75 The Foreshore and Seabed Act: Five years on, where to from here? in Maori and the environment:Kaitiaki Edited Selby, Moore andf Mulholland Huia Publishers

Zemgulys, Andrea 2008 Modernism and the Locations of Literary Heritage. Pp. viii +248 . Cambridge: Cambridge University Press 